Research Article

\title{
Comparative Analysis the Coverages of Filariasis Mass Prevention Drug (POPM) in Central Java Year 2018: Case Study in Grobogan, Semarang, and Wonosobo
}

\author{
Setya Ningrum ${ }^{1}$, Rokhmayanti Rokhmayanti ${ }^{1^{*}}$, Mieng Nova Sutopo ${ }^{2}$ \\ ${ }^{1}$ Faculty of Public Health, Ahmad Dahlan University, Yogyakarta, Indonesia \\ ${ }^{2}$ Center for Environmental Health Engineering and Disease Control, Yogyakarta, Indonesia
}

*Correspondence: rokhmayanti@ikm.uad.ac.id. Tel: +6281229517992

Received 10 February 2020; Accepted 31 March 2020; Published 01 April 2020

\begin{abstract}
Background: Filariasis is a disease caused by filarial worms and transmitted by mosquitoes that contain filarial worms. Pemberian Obat Pencegahan Masal (POPM) filariasis or Mass Prevention Drug is a program aimed to reduce the number of filariasis. The Survey of POPM in Grobogan, Semarang, and Wonosobo, shows there are different coverages of $65 \%$ and $85 \%$. The purpose of this study is to compare the survey coverage of POPM filariasis. Seek the reason not to participate, and the characteristics of the respondents who did not take filariasis medicine in Grobogan, Semarang, and Wonosobo.

Methods: Descriptive quantitative study was used in this study by collecting secondary data of POPM survey coverage in Grobogan, Semarang, and Wonosobo year 2018. Descriptive and comparative analysis was applied to respondent characteristics, filaria POPM coverage, and elaborate the unconformity to the filaria medication.

Results: Grobogan coverage is low compared to Semarang and Wonosobo. The respondent said about traveling, don't know, and age as the reason to not take the filariasis medication. Conclusions: Among the three districts, Grobogan is the district with low filariasis medication coverage compared to Semarang and Wonosobo.
\end{abstract}

Keywords: Filariasis, POPM, Grobogan, Semarang, Wonosobo

\section{INTRODUCTION}

Filariasis is a chronic infectious disease caused by the filarial worms and transmitted by mosquitoes that contain filarial worms in their body. The worm grows into an adult in the human body and settles in the lymphatic tissue, causing swelling in the feet, legs, breasts, arms, and genital organs (1). Currently, globally there are 1.3 billion people at risk of transmitting the filariasis that spreads in more than 83 countries, and $60 \%$ of cases are in Southeast Asia (2).

In Indonesia, found three species of filarial worms: Wuchereria bancrofti, Brugia malayi, and Brugia timori (3). From 2014-2018, 2014 was the highest filariasis case, recorded 14,932 cases during that year, and declined in 2018 with 10,681 cases. Filariasis in Indonesia spread across 34 provinces. Five provinces with the most cases of chronic filariasis are Papua, East Nusa Tenggara, West Java, West Papua, and Aceh (2). In Central Java, in 2018, there were 439 cases of chronic filariasis that mostly found in nine districts/cities that became endemic 


\section{Epidemiology and Society Health Review $\mid \mathbf{E S H R}$}

areas: Pekalongan, Pekalongan, Brebes, Wonosobo, Semarang, Grobogan, Blora, Pati and Demak (4).

Indonesia Minister of Health leads the filaria control program under the regulation No. 94 the Year 2014 about filariasis elimination. This regulation states about the main activity on the elimination is implementing a POPM (Filariasis Mass Prevention Drug) program. Filaria elimination goal is reducing the microfilariae number to less than $1 \%$ in each district. Surveys of the program implementation can identify filariasis POPM coverage.

The POPM filariasis coverage survey was conducted for all people living in endemic filariasis areas. The subject of this survey is divided into two groups, namely POPM target, and nonPOPM target respondents. POPM target is each residence who aged 2-70 years in all education levels. Non POPM target respondents are every residence outside the target group, such as pregnant women, people with chronic illness, aged less than 2 years, and above 70 years. POPM filariasis coverage is measured by two categories: $65 \%$ coverage and $85 \%$ coverage. $65 \%$ coverage is the ratio of the number of respondents taking the drug, with the total number of respondents multiplied by $100 \%$. High coverage for this standard means the proportion of taking medication is above $65 \%$ for all respondents. $85 \%$ coverage is the ratio of the number of respondents taking the drug with the number of target respondents multiplied by $100 \% .85 \%$ coverage can be called as high if the proportion of taking filaria drugs is above $85 \%$ of the target respondents (5)-(7).

$$
65 \% / 85 \% \text { coverage }=\frac{\text { Number of respondent takes filaria drug }}{\text { All respondens }} \times 100 \%
$$

In $65 \%$ target coverage, Grobogan, Semarang, and Wonosobo are stand in $81 \%, 84 \%, 83 \%$, respectively. When in $85 \%$ target coverage, they stand in $85 \%, 91 \%$, and $91 \%$, respectively (5)(6)(7). This study aims to compare the coverage of POPM filariasis and people's motivation not to participate, include their characteristics in Grobogan, Semarang, and Wonosobo.

\section{METHODS}

Descriptive quantitative design was applied to illustrate the comparative results POPM filariasis coverage in Grobogan, Semarang, and Wonosobo year 2018. The table and graphics were used to display the result. Secondary data (POPM coverage filariasis) was collected from BBTKLPP Yogyakarta from 5-31 August 2019. This data based on the BBTKPLPP survey year 2018. The population of this research was all people aged 2-70 years living in Grobogan, Semarang, and Wonosobo, they are not pregnant, not sick, aged not less than two years and not more than 70 years were included in this study. In three districts (Grobogan, Semarang, and Wonosobo), we included 1,115; 1,242 and 1,170 respondents, respectively. The analysis was performed using descriptive and comparative analysis.

\section{RESULTS}

Comparisons of filariasis medication compliance in Grobogan, Semarang and Wonosobo year 2019

According to the data, Grobogan, Semarang, and Wonosobo have reached the national target $(65 \%$ and $85 \%)$ (Figure 1). Filaria POPM coverage in three districts was categorized as high both for $65 \%$ and $85 \%$ measure. On $65 \%$ target, Semarang is the district with the highest 
coverage (84\%), and in $85 \%$ target, Semarang and Wonosobo have similar coverage $(91 \%)$. This result implies in Semarang and Wonosobo, POPM targets have high conformity to take filaria drugs compared to Grobogan.

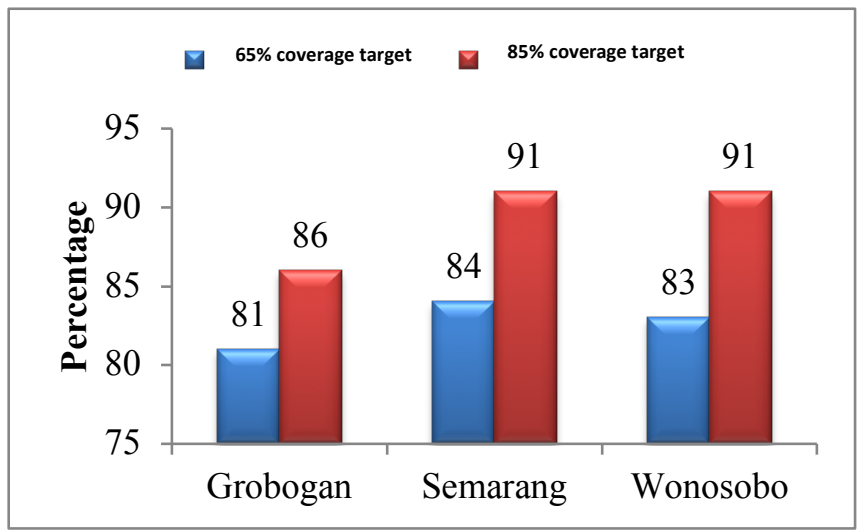

Source: BBTKLPP Yogyakarta, 2018

Figure 1. Results of Drinking Drug Coverage Filariasis in Grobogan, Semarang and Wonosobo 2018

The reason to not comply with filariasis medication in Grobogan, Semarang and Wonosobo year 2018

Among the three districts, Grobogan has the highest number of not conforming people to filariasis medication (208 people) compared to Semarang and Wonosobo, with 204 people each of them. However, the differences among them are not significant. Non-POPM targets said about pregnant, sick, and age reason to not adhere to the program. While for POPM target they said refuse, don't know, travel and other specific reasons (Table 1)

Table 1. The motivation of people to not comply with filariasis medications in Grobogan, Semarang and Wonosobo 2018

\begin{tabular}{|c|c|c|c|c|}
\hline \multirow[t]{2}{*}{ No. } & \multirow[t]{2}{*}{ Reason } & \multicolumn{3}{|c|}{ Number of people } \\
\hline & & Grobogan & Semarang & Wonosobo \\
\hline \multirow[t]{3}{*}{1} & Not POPM Target & & & \\
\hline & Pregnant & 11 & 13 & 16 \\
\hline & Sick & 16 & 28 & 46 \\
\hline & Age & 44 & 62 & 53 \\
\hline \multicolumn{2}{|c|}{ Amount } & 71 & 103 & 115 \\
\hline \multirow[t]{5}{*}{2} & POPM Target & & & \\
\hline & Refuse & 25 & 18 & 7 \\
\hline & Do not know & 28 & 49 & 9 \\
\hline & Travel & 64 & 32 & 54 \\
\hline & $\begin{array}{l}\text { Other: Breastfeeding, do not have } \\
\text { an ID card, forget to drink, without } \\
\text { explanation }\end{array}$ & 20 & 2 & 19 \\
\hline \multicolumn{2}{|c|}{ Amount } & 137 & 101 & 89 \\
\hline \multicolumn{2}{|c|}{ Total } & 208 & 204 & 204 \\
\hline
\end{tabular}

Source: BBTKLPP Yogyakarta, 2018 


\section{Epidemiology and Society Health Review $\mid \boldsymbol{E S H \boldsymbol { R }}$}

\section{Characteristics of POPM Target Who Not Take Filariasis Drugs in Grobogan, Semarang and Wonosobo year 2018}

Table 2 shows that Grobogan is the district with people's POPM target but not comply with the program. In three districts, most of the respondents are aged 16-70 years, hold primary school, and the majority of them are male (Table 2).

Table 2. Characteristics of POPM Target Who Not Take Filariasis Drugs in Grobogan, Semarang and Wonosobo year 2018

\begin{tabular}{|c|c|c|c|c|}
\hline \multirow[t]{2}{*}{ No. } & \multirow[t]{2}{*}{ Characteristics } & \multicolumn{3}{|c|}{ Number of Respondents (People) } \\
\hline & & Grobogan & Semarang & Wonosobo \\
\hline \multirow[t]{4}{*}{1} & Age group (Yo) & & & \\
\hline & $3-5$ & 14 & 3 & 3 \\
\hline & $6-15$ & 11 & 14 & 7 \\
\hline & $16-70$ & 112 & 84 & 79 \\
\hline \multicolumn{2}{|c|}{ Amount } & 137 & 101 & 89 \\
\hline \multirow[t]{4}{*}{2} & Level of education & & & \\
\hline & Pre-School & 15 & 12 & 4 \\
\hline & $\begin{array}{l}\text { Basic School (Primary and } \\
\text { Junior High School) }\end{array}$ & 88 & 49 & 59 \\
\hline & $\begin{array}{llr}\text { Advance School } & \text { Senior } \\
\text { High School } & \text { and } \\
\text { University) } & \end{array}$ & 34 & 40 & 26 \\
\hline \multicolumn{2}{|c|}{ Amount } & 137 & 101 & 89 \\
\hline \multirow[t]{3}{*}{3} & Gender & & & \\
\hline & Male & 75 & 61 & 46 \\
\hline & Female & 62 & 40 & 43 \\
\hline \multicolumn{2}{|c|}{ Amount } & 137 & 101 & 89 \\
\hline
\end{tabular}

Source: BBTKLPP Yogyakarta, 2018

\section{DISCUSSIONS}

Grobogan is the district with low coverage of POPM. Some factors are influencing the low coverage of POPM filaria. For example, the information does not meet the target due to geographic conditions, inadequate communication facilities, people not in place when the program held, farming, schooling, insufficient knowledge and awareness of the community to take medicine. On the other hand, the POPM low coverage shows the weak performance of POPM staff. While the little POPM coverage compared to the target presents the unsuccessful of the medication (8).

The geographical conditions of Grobogan may be the reason for this situation. The various geographic area: plains, hills, and plateau could be a barrier for POPM staff to deliver information about POPM filariasis. Another reason, this district consists of mostly by productive age group (15-64 years), which is most of them do the activity away from they reside, such as schooling, laboring in other places. Accordingly, they are not in place when POPM was held. These results are consistent with research Harfaina et al. (2019), which stated there is a significant relationship between job by taking medicine filariasis (9).

Knowledge among the community in Grobogan is categorized as high indicated from the level of education in general. Unfortunately, it is in contrast with the low level of awareness on taking filaria medication. This is in line with research Nurlaila et al. (2017), who stated that there is a significant relationship between knowledge versus the conformity on medication filariasis (10). 


\section{Epidemiology and Society Health Review $\mid \boldsymbol{E S H R}$}

A similar result was found by Rusmini and Suryawan (2014), who said there is no significant relationship between education versus filariasis medication. A busy person might neglect to take the filariasis drug (11). However, a person with good knowledge will have better health awareness, such as they comply with taking filaria medications because he knows the benefits of the drug compared to those who are not knowledgeable. Indeed, education was influencing the acceptance of health information, but education does not directly influence people to decide on to participate in the health program (12).

Semarang obtains the highest coverage compared to other districts. It demonstrates the high public awareness of the Semarang District to participate in taking medicine filariasis. This achievement shows high awareness among the Semarang population and the high performance of the health staff. On the other hand, indeed, the mobility of Semarang people is low compared to Grobogan due to the industrial setting in Semarang (13). Accordingly, people easy to meet with the POPM staff when the program held because they are in place. In addition, the high coverage of POPM filariasis is influenced by community participation on the take the drug, funding efficiency in socialization (14).

Increasing public knowledge about filariasis and the importance of taking medication is necessary for people who live in areas with filariasis endemic. Finding the way out for working people that also need to take medicine is essential to avoid the failure medication among them. If community participation on the POPM filaria program is excellent, it is expected the incidence of filariasis in Grobogan, Semarang, and Wonosobo can be reduced (15).

In the three districts, people as POPM targets have a similar reason for their unconformity to filaria medication. Most of them said about children less than 2 years or more than 70 years. It is following the program that targeting people in 2-70 years. Some of them talked about the side effect of the filaria drug, such as fever, headache, muscle aches, nausea, and dizziness. Another reason for the unconformity is the lack of information about the program that due to people's activities such as working, studying, or temporarily not living in the area. So, when health staff conducts socialization, they not in place. In addition, they talked about breastfeeding and the difference in address between the current location and what is written on the national identity card (KTP) (16).

Indonesian government uses DEC dan Albendazole on the filaria program. According to the national guidelines, DEC is allowed to be given to pregnant women but not allowed to children under 2 years. While Albendazole, totally prohibited for children under 2 years, pregnant woman, and sick person (17). The regulation considers the side effect of the two drugs. For example, Albendazole can cause alopecia or hair loss in high consumption of this drug ( $800 \mathrm{mg} /$ day). A pregnant woman is not the POPM target because Albendazole is embryogenic or embryo growth problem. In children aged under two, the safety is unknown, so the allocation of this drug is prohibited. While at people aged more than 70 years, the forbidden on using this drug-related decreased organ performance in the elderly (18).

Another reason to not participate in the POPM program is not in place or traveling for many purposes, such as work or schooling. In Semarang for POPM target said that don't know or lack of POPM information as to their reason for not participating in the program. This is in line with research Astuti, et al. (2014), which states that there is a significant relationship between the socialization of health workers to take medication POPM filariasis (19). In this case, the lack of health promotion on POPM may lead the inadequate coverage of filariasis.

The characteristics of POPM filariasis respondents in Grobogan, Semarang, and Wonosobo year 2018 mostly the same: aged 16-70 years, have primary education and are male. People who are holding primary school are the high proportion who not comply with the medications. 


\section{Epidemiology and Society Health Review $\mid \boldsymbol{E S H \boldsymbol { R }}$}

According to Alam and Marlina (2016), education is not related to filariasis medication; however, knowledge has an association with filariasis medication (20).

In this study, males mostly un-conform with filariasis medication. This is in line with the results of research Isabella, et al. (2018), which states that there is a significant relationship between the sex by taking medicine filariasis. Female found more conform to taking filaria medicine than the male. This is because the majority of men are working while most women are staying at home. As a result, most of the man does not take the medication for his absence related work (21).

\section{CONCLUSIONS}

Grobogan coverage is low compared to Semarang and Wonosobo. The respondent said about traveling, don't know, and age as the reason to not take the filariasis medication.

\section{Authors' Contribution}

SN contributed to the data collection, data analysis, and report writing and manuscript publication, RR contributed to licensing, data analysis, and report writing. MN participated as a provider of data and information, data analysis, and report writing.

\section{Funding}

This research has not received external funding

\section{Acknowledgments}

Thanks to the Center for Disease Control Environmental Health Engineering (BBTKL PP) Yogyakarta, which has provided the data and information in the study.

\section{Conflict of Interest}

There is no conflict of interest in this research.

\section{REFERENCES}

1. Yamin RA. Determinan Filariasis. Sidoarjo: Uwais Inspirasi Indonesia; 2019.

2. Kementerian Kesehatan RI. Profil Kesehatan Indonesia 2018. Jakarta: Kementerian Kesehatan Rl; 2019.

3. Goel TC, Goel A. Lymphatic Filariasis. Singapura: Springer; 2016.

4. Dinas Kesehatan Jawa Tengah. Profil Kesehatan Provinsi Jawa Tengah Tahun 2018. Semarang: Dinas Kesehatan Provinsi Jawa Tengah; 2019.

5. BBTKLPP Yogyakarta. Survei Cakupan POPM Filariasis dan Kecacingan Terpadu di Kabupaten Grobogan, Jawa Tengah Tahun 2018. Yogyakarta: BBTKLPP Yogyakarta; 2018.

6. BBTKLPP Yogyakarta. Survei Cakupan POPM Filariasis dan Kecacingan Terpadu di Kabupaten Semarang, Jawa Tengah Tahun 2018. Yogyakarta: BBTKLPP Yogyakarta; 2018.

7. BBTKLPP Yogyakarta. Survei Cakupan POPM Filariasis dan Kecacingan Terpadu di Kabupaten Wonosobo, Jawa Tengah Tahun 2018. Yogyakarta: BBTKLPP Yogyakarta; 


\section{Epidemiology and Society Health Review $\mid \boldsymbol{E S H R}$}

2018.

8. Habibah Z, Sungkar S. Cakupan Pemberian Obat Pencegahan Massal Filariasis di Kabupaten Sumba Barat Daya Tahun 2012-2013. J Kedokt Indones. 2015;3(3):199_ 203.

9. Harfaina, Hadisaputro S, Lukmono DT, Sakundarno M. Faktor-faktor yang Mempengaruhi Ketidakpatuhan Minum Obat Sebagai Upaya Pencegahan Filariasis di Kota Pekalongan. J IIm Permas J IIm STIKES Kendal. 2019;9(1):1-6.

10. Nurlaila, Ginandjar P, Martini. Faktor-faktor yang Berhubungan dengan Kepatuhan Pengobatan Masal di Kelurahan Non Endemis Filariasis Kota Pekalongan. J Kesehat Masy. 2017;5(4):455-66.

11. Rusmini H, Suryawan B. Faktor-faktor yang Mempengaruhi Sikap dan Perilaku Masyarakat Terhadap Kepatuhan Minum Obat Anti Filariasis di Kabupaten Bogor. J Med Heal Sci. 2014;1(3):1-15.

12. Rahardjo S, Kusumawati E. Hubungan Tingkat Pendidikan dan Pengetahuan dengan Perilaku Keluarga Sadar Gizi (KADARZI) pada Masyarakat Perkotaan dan Perdesaan di Kabupaten Banyumas. J Kesmasindo. 2011;4(2):150-8.

13. BPS Kabupaten Semarang. Statistik Daerah Kabupaten Semarang 2018. Ungaran: Badan Pusat Statistik Kabupaten Semarang; 2018.

14. Munthe S, Suryoputro A, Margawati A. Kinerja Petugas Kesehatan Program Penanggulangan Filariasis Pada Kegiatan Pemberian Obat Pencegahan Secara Massal (POPM) Filariasis di Kabupaten Nagekeo Nusa Tenggara Timur. Public Helath Sci J. 2018;10(2):1-8.

15. Anorital, Marleta DR, Kristina P. Studi Kajian Upaya Pemberian Obat Pencegahan Masal Filariasis Terhadap Pengendalian Penyakit Infeksi Kecacingan. J Biotek Medisiana Indones. 2016;5(2):95-103.

16. Sulistyaningsih N, Musthofa SB, Kusumawati A. Persepsi Masyarakat Terhadap Program Eliminasi Filariasis Melalui (POMP) Sebagai Upaya Pencegahan Filariasis di Kecamatan Bonang, Kabupaten Demak. J Kesehat Masy. 2018;6(1):780-91.

17. Kementerian Kesehatan RI. Kepmenkes RI Nomor 893/MENKES/SKVIII/2007 Tentang Pedoman Penanggulangan Kejadian Ikutan Pasca Pengobatan Filariasis. 2007.

18. Wahyono TYM, Purwantyastuti, Supali T. Filariasis di Indonesia. Bul Jendela Epidemiol. 2010;1(2):15-9.

19. Astuti EP, Ipa M, Wahono T, Ruliansyah A. Analisis Perilaku Masyarakat Terhadap Kepaatuhan Minum Obat Filariasis di Tiga Desa Kecamatan Majalaya Kabupaten Bandung Tahun 2013. Media Litbangkes. 2014;24(4):199-208.

20. Alamsyah A, Marlina T. Faktor-faktor yang Berhubungan dengan Cakupan Menelan Obat Massal Pencegah Filariasis. J Endur. 2016;1(1):17-21.

21. Isabella, Fitriangga A, Natalia D. Determinan Kepatuhan Minum Obat Anti Filariasis pada Masyarakat Desa Selat Remis Kecamatan Teluk Pakedai. J Kesehat Khatulistiwa. 2018;4(2):640-56. 
Epidemiology and Society Health Review $\mid \boldsymbol{E S H R}$ 